\title{
Hard Rock Mining
}

National Cancer Institute

\section{Source}

National Cancer Institute. Hard Rock Mining. NCI Thesaurus. Code C156866.

A process and occupation involving the excavation of hard minerals or their ores from the ground. 